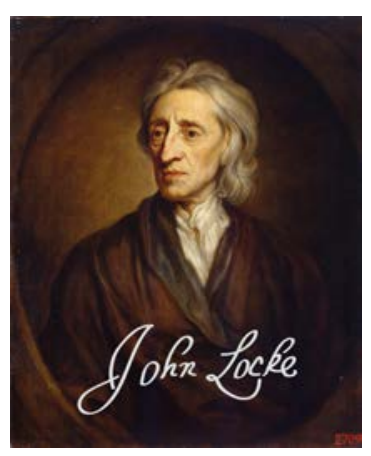

LOCKE STUDIES

Vol. 19

https://doi.org/10.5206/ls.2019.6246 | ISSN: 2561-925X

Submitted: 3 JANUARY 2019

Published online: 19 JANUARY 2019

For more information, see this article's homepage.

(c) 2019. Patrick J. Connolly

\title{
Review of Richard Baxter and the Mechanical Philosophers by David Sytsma
}

\author{
PATRICKJ . CONNOLLY (LEHIGH UNIVERSITY)
}

Abstract: A review of David Sytsma's recent book, Richard Baxter and the Mechanical Philosophers (New York: Oxford University Press, 2017).

Keywords: Richard Baxter, mechanical philosophers, philosophy, reason, faith, religious belief, theology 


\section{Sytsma, David. Richard Baxter and the Mechanical Philosophers. New York: Oxford University Press, 2017. 352 pp. \$99 (hbk). ISBN: 9780190274870.}

\section{Reviewed by PATRICKJ . CONNOLLY}

In Richard Baxter and the Mechanical Philosophers David Sytsma sets himself an admirable goal. He seeks to capture and make accessible to readers the systematic philosophical thought of Richard Baxter (1615-1691). Although Baxter enjoys some recognition among historians of Puritanism, he does not have much of a reputation among even those who specialize in seventeenth-century British philosophy. But given his substantive engagement with the philosophers and philosophical issues of the day, and given his interesting and often innovative take on matters of central philosophical concern, this book makes the case that he deserves a closer look.

As Sytsma is well aware, there are a number of serious challenges awaiting any scholar seeking to make sense of Baxter's philosophical legacy. For one thing, there is the sheer size of his corpus. His published works are voluminous and exhibit a great deal of variety in terms of style and subject matter. Among his works it can very often be difficult to separate the polemical from the systematic, the philosophical from the strictly theological, and perhaps most importantly, the practical from the theoretical. Baxter's manuscript remains are similarly daunting in size and until the very recent publication of Alan Argent's The Richard Baxter Treatises: A Catalogue and Guide (Woodbridge, UK: Boydell \& Brewer, 2018) they were poorly catalogued. And, of course, Baxter was a prolific correspondent leaving behind hundreds of letters and literary exchanges. So getting to grips with Baxter's literary output is the first challenge. There is also the fact that Baxter was an omnivorous reader and an eclectic thinker, keen to match his own views up to those of his predecessors and contemporaries. So his works are very often steeped in the ideas, language, and frameworks of several other authors and traditions. This adds complexity to Baxter's prose, which is already heavy and sometimes difficult to parse. Untangling this web is no small task. Finally, there is the fact that Baxter is something of a strange thinker. His views are very often idiosyncratic, and I suspect they may appear somewhat eccentric to many readers familiar with the more canonical philosophical texts of the early modern period.

In the first chapter of the book, "Richard Baxter as Philosophical Theologian," Sytsma provides the motivation for his project. Sytsma points to contemporary sources that make it clear Baxter was widely regarded as an influential thinker who left an important intellectual legacy before then going on to analyze the ways in which various historiographical trends have distorted the image that we have of Baxter and his thought. Part of the problem here has to do with the fact that those working on the history of philosophy and those working on the history of theology are not always working in concert. But even while Baxter has received attention from historians of theology, there has been undue emphasis on his practical and devotional works and neglect of his philosophical interests. The scholarship also contains conflicting strands when it comes to Baxter's attitude toward the tremendously important developments in natural philosophy that occurred during his lifetime. Some cast him as a proponent of these developments and some as a critic. Sytsma argues that previous scholars are correct to see an important link between Baxter and these developments in natural philosophy. According to him, Baxter's engagement with natural philosophy, in particular with the 
revival and reception of the mechanical philosophy in Britain, was one of the main animating features of his thought. Baxter's key contribution to early modern philosophy was a product of his efforts to understand the philosophical difficulties inherent in mechanism and to clearly elucidate the sense in which it posed a threat to orthodox Christianity.

Chapter 2 provides important background by way of a historically detailed recounting of the way Epicureanism, primarily filtered through Pierre Gassendi, came to shape philosophical thought in Britain during the period. Sytsma juxtaposes this richly contextualized account with a helpful chronology of Baxter's own career, including his exchanges with important thinkers like J oseph Glanvill, Matthew Hale, and Henry More. With this historical background in place, Chapters 3 and 4 seek to provide the systematic philosophical background for Baxter's engagement with the mechanical philosophy. Chapter 3 tackles one of the most difficult topics for any seventeenth-century thinker: the scope and limits of reason and its relationship to faith and religious belief. One of Sytsma's main aims is to push back against overly rationalist interpretations of Baxter and to emphasize his Puritan bona fides. That being said, Baxter's views on this issue exhibit considerable complexity and Sytsma guides the reader through a number of twists and turns. Chapter 4 discusses Baxter's approach to natural philosophy. As ever, in this domain Baxter's thought was highly eclectic but the overarching theme of the chapter is the Trinitarian framework that Baxter employed to make sense of the natural world. According to the medieval tradition of Vesitigia Trinitatis key features of the created world echo the tripartite structure of the Christian God. For Baxter, this means a threefold approach to things like the elements that compose material objects and the types of causal force in the natural world. Like much else in Baxter, this view can initially seem somewhat obscure. But Sytsma is surely correct that it presents a fascinating and useful contrast to the sort of physico-theology endorsed by so many of Baxter's contemporaries.

Chapter 5, entitled "A Commotion Over Motion," is the most central to the overall project of the book. The chapter discusses a number of key issues (e.g., Copernicanism, substantial forms, inertia, laws of nature) and figures (e.g., René Descartes, Henry More) in early modern natural philosophy. But the central concern is with how to account for change in the natural world. This discussion primarily centers on motion, but motion is really just one way to conceptualize the variety of changes and processes observed in nature. Baxter was aligned with the mechanical philosophy insofar as he was willing to endorse a form of corpuscularianism. But like a number of other thinkers in the period he struggled to understand how purely passive or entirely inert material corpuscles could really be sufficient to explain all the motion and activity present in the material world. While some of the difficulties for the mechanical philosophy that Baxter identifies are familiar, others are less familiar and make for very interesting reading. Also interesting is his positive proposal that an array of secondary causes possess genuine agency and that it is these active natures or living souls that produce motion and activity. Thus Baxter's corpuscularianism is much more like Daniel Sennert's or Kenelm Digby's than like Thomas Hobbes's or Robert Boyle's.

Having examined Baxter's treatment of mechanism and natural philosophy the final two chapters turn to his evaluation of the moral threats posed by Epicurean thought. Chapter 6, perhaps the most interesting of the chapters, explores Baxter's fears that the mechanical philosophy carried the seeds of a problematic materialism and would lead to a denial of the human soul. Needless to say, for someone as devout as Baxter a denial of 
the soul or its immortality was anathema. One particularly interesting feature of the chapter is Sytsma's exposition of a previously ignored manuscript in which Baxter engages the views of the famous anatomist Thomas Willis. Willis had developed a sophisticated materialist account of animal souls. Baxter, seeing this as the thin end of the materialist wedge, was eager to offer a reply. Chapter 7 is concerned with moral theory proper. Many early modern thinkers wanted to accept the mechanism of figures like Descartes and Gassendi but reject the moral theory of mechanist thinkers like Hobbes and Spinoza. Baxter saw a deep connection between the two and felt that this was impossible; so his critique of mechanist physics set him up for a critique of mechanist ethics. Baxter endorsed a version of natural law theory as a safe alternative to the necesitarianism implicit in the mechanical worldview.

In the preface Sytsma tells us that one of his goals is to help facilitate interdisciplinary awareness and dialogue between historians of philosophy and historians of theology. This is a task more difficult than it seems, and Sytsma should be applauded for his success in achieving this goal. In large part, this success is due to the fact that the book is spectacularly well-researched. The footnotes are jam-packed with references to literature in both history of philosophy and history of theology as well as to contemporary seventeenth-century sources. They contain any number of tantalizing pointers for interested readers to chase up. Sytsma has left very few stones unturned in his review of the literature, including works from the first half of the twentieth-century and works in French and German.

It was claimed above that there are challenges facing interpreters of Baxter. As should now have become clear, Sytsma has conquered nearly all of them. In facing the size of the corpus, he freely admits to having made choices about what to include and to have focused his attention selectively. But he gives evidence of having scoured Baxter's writing top to bottom and shows facility with an impressive number of primary sources. He has also successfully navigated Baxter's eclecticism by providing the necessary background information about various topics, figures, and debates before showing how Baxter wound his own, principled but highly idiosyncratic, way through complex argumentative terrain to stake out his positive views. Sytsma should also be commended for striking a nice balance between quotations from Baxter that let him speak in his own voice and reconstructions of the text; this helps to overcome some of difficulties arising from Baxter's sometimes troubling form of expression.

There is one challenge that I believe Sytsma has had a harder time meeting. One goal of the book is to help readers to see what Baxter was like as a philosopher, and the truth of the matter is that Baxter is philosopher who is somewhat hard to get to know. In reading the book, it is nearly always clear what Baxter thought about a particular issue, but it can be much more difficult to see why he thought this. It is hard to see why hewould emphasize a particular concept, why he would take one argumentative route rather than another, why he would concede one point but fight another so vociferously. In short, it can be difficult to get a sense for what "makes him tick" as a thinker. This is not a criticism of Sytsma so much as a criticism of Baxter himself. Sentences like the following, from page 131, might help to give some sense of the difficulty of Baxter's thought: "While it is true, as we shall discuss below, that Baxter drew upon Campanella's primalities as a philosophical expression of this Trinitarian analogical communication of God's attributes, the theological antecedents to this aspect of Baxter's thought in the Reformed tradition have been inadequately appreciated." 
But while the thorny nature of Baxter's thought can be frustrating, there are also important benefits to engaging with a philosopher who holds such a unique set of views. For example, in Chapter 6 it is refreshing to see Baxter upset one common narrative about early modern thinking on the soul. For many, it was obvious that the immateriality of the soul guaranteed its immortality. But Baxter has an argument to the effect that the soul's immortality should rest on its essential formal powers, rather than on its more accidental features. Whatever one makes of his positive argument for the immortality of the soul (a broadly Thomistic one that humans have an inclination toward goodness, truth, and immortality and that natural desires are not in vain), it is illuminating and interesting to see his challenge to the familiar association of immateriality with immortality.

It is fairly obvious that Sytsma's book will set both the standard and the agenda for Baxter scholarship for many years to come. But its importance lies in more than that. It can be profitably read not just by those antecedently interested in Baxter. Scholars concerned with Margaret Cavendish, Anne Conway, Ralph Cudworth, Descartes, Gassendi, Hobbes, Gottfried Leibniz, J ohn Locke, More, or any number of other figures will surely benefit from learning about Baxter and comparing and contrasting him with their philosopher of special interest. More generally, the book is valuable because it provides us with the opportunity to challenge some widely held preconceptions and to see and think about early modern philosophy in a different way. For this, as much as anything, we should be grateful to Sytsma.

Lehigh University 